\title{
小児気管支喘息急性増悪患者に㧍ける 呼吸理学療法の検討
}

\author{
Respiratory Physical Therapy for Children Hospitalized with Acute Severe Asthma
}

内尾 優 ${ }^{1,4)}$ 志真 奈緒子 1) 圖師 将也 ${ }^{1)}$ 永田 智 ${ }^{2)}$ 猪飼 哲夫 ${ }^{3)}$

YUU UCHIO, RPT, MSc ${ }^{1,4)}$, NAOKO SHIMA, RPT ${ }^{1)}$, MASAYA ZUSHI, RPT ${ }^{1)}$,

SATORU NAGATA, MD, $\mathrm{PhD}^{2)}$, Tetsuo IKAI, MD, $\mathrm{PhD}^{3)}$

${ }^{1)}$ Department of Rehabilitation, Tokyo Women's Medical University: 8-1 Kawada-cho, Shinjuku-ku, Tokyo 162-8666, Japan

${ }^{2)}$ Department of Pediatrics, Tokyo Women's Medical University

3) Department of Rehabilitation Medicine, Tokyo Women's Medical University

4) [Present] Department of Rehabilitation, Faculty of Health Sciences, University of Tokyo Health Sciences: 4-11 Ochiai, Tama-shi, Tokyo 206-0033, Japan TEL +81 42-373-8118 E-mail: yu-uch-247@u-ths.ac.jp

Rigakuryoho Kagaku 35(3): 439-442, 2020. Submitted Dec. 23, 2019. Accepted Jan. 21, 2020.

ABSTRACT: [Purpose] This study investigated the efficacy of chest physical therapy for children hospitalized with acute severe asthma. [Participants and Methods] The study included 20 children with acute severe asthma but without major neurological impairment. The mean age of the children was $2.5 \pm 1.3$ years. Findings on admission and clinical care were examined. The children were categorized into chest physical therapy and non-chest physical therapy groups, and the evaluation items were compared between the two groups. [Results] No significant intergroup differences were observed in oxygen weaning and length of hospitalization. [Conclusion] These results suggest that chest physical therapy enables neither early oxygen weaning nor early discharge of children hospitalized with acute severe asthma.

Key words: asthma, atelectasis, respiratory physical therapy

要旨：〔目的〕小児気管支喘息急性増悪患者に対する胸郭圧迫介助法の効果について検討した。〔対象と方法〕対象 は, 当院へ入院した神経学的異常を認めない平均 $2.5 \pm 1.3$ 歳の小児気管支喘息患者 20 名とした. 対象を吸入時の 徒手的な呼吸介助手技実施の有無により呼吸介助実施群 11 名, 非実施群 9 名の 2 群に分け, 診療録により入院時所見, 入院中治療経過を検討，比較した。〔結果〕 2 群間において入院から酸素投与中止までの日数，入院期間には統計的 な差はなかった， 2 群ともに入院中新たな無気肺を併発した症例はいなかった。〔結語〕乳幼児気管支喘息急性増悪 患者に対する徒手的な呼吸介助手技は酸素投与中止までの日数や早期退院には寄与しない可能性が示唆された.

キ一ワード : 気管支喘息, 無気肺, 呼吸理学療法

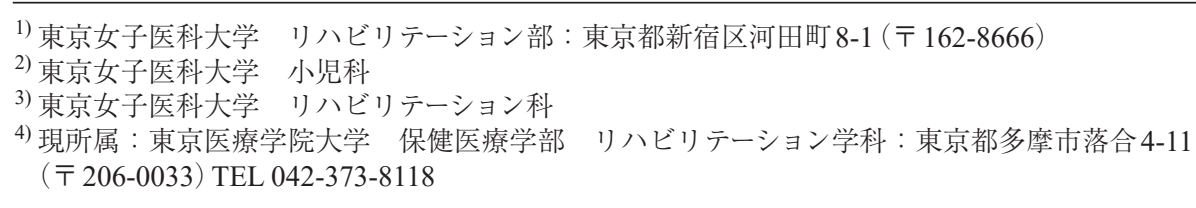

受付日 2019 年 12 月 23 日 受理日 2020 年 1 月 21 日 


\section{I.はじめに}

気管支喘息は，慢性気道炎症により，発作性に生じる 気道狭窄によって，喘鳴や咳嗽を繰り返す疾患である． 近年では, 小児気管支喘息治療の発展により, 喘息死や 長期入院患者は激減している 1 )。また，急性増悪による 入院患者数は減少傾向にあるものの, 依然として相当数 の入院患者が存在しているのが現状であり，その多くを 1 4 歳の乳幼児が占めている ${ }^{2)}$. 気管支喘息の急性増 悪では，状態が悪化すれば呼吸不全に陥る可能性がある ため, 早期からの適切な治療が必要である.

気管支喘息の急性増悪に対する治療は，気管支拡張薬 の吸入，副腎皮質ステロイドの全身投与 ${ }^{3)}$, 酸素投与が 主に行われる。副次的な治療，また急性増悪の合併症で ある無気肺や肺虚脱による呼吸不全の増悪を予防する観 点から，入院時には呼吸理学療法を実施する場合があ る. 呼吸理学療法とは, 呼吸障害の治療と予防を目的と し, 状態に応じて胸郭圧迫介助法, 排痰法, 体位管理, 体位ドレナージなどが行われる，従来，小児気管支喘息 急性増悪患者に対して, 介助者が両手掌を前胸部から外 側胸部を包み込むようにあてがい，呼気とともに軽く押 し下げる胸郭圧迫介助法が吸入時に併用して実施され， 施行直後の酸素飽和度, スパイロメトリーによる一秒量 努力性肺活量が改善したとの報告がなされている4,5). しかし, 急性増悪の改善や入院期間の短縮など短期的な 治療の改善について検討された報告は少ない，また，咳 嗽・喀痰の診療ガイドライン 20196)によれば，喘息に 対する徒手的な介入を支持するエビデンスはそしいこと が報告されており，気管支喘息患者に対する呼吸理学療 法の胸郭圧迫介助法実施については議論の余地がある.

当院では従来，気管支喘息急性増悪患者に対し徒手的 な呼吸介助手技を気管支拡張薬の吸入に合わせて行って きた， 2018 年度より担当班体制の変更に伴い，小児気 管支喘息治療・管理ガイドライン 20177) にて推奨され ている吸入時の指導を中心とした介入方法へ変更し, 徒 手的な呼吸介助手技を実施しなかった。

そこで, 本研究では, 従来の介入方法と 2018 年度以 降の介入方法を比較することで, 小児気管支喘息急性増 悪患者に対する呼吸介助手技の酸素離脱と入院期間への 効果を明らかにすることを目的とした。

\section{II. 対象と方法}

\section{1. 対象}

対象は, 2017 年 4 月から 2019 年 3 月までの間に東京 女子医科大学病院小児科に入院し,リハビリテーション 依頼のあった小児気管支喘息急性増悪患者とした，選択 基準は, (1)年齢 5 歳未満の児とした。除外基準は, (1)脳 性麻痖の診断を受けている児, (2)染色体異常・神経筋疾
患を合併した児，(3)入院中に死亡した児とした．

\section{2. 方法}

診療録より，対象者の背景，入院時所見，入院中治療 経過について調査した。

対象者の背景は，性別，診断名を，入院時所見は，発 作強度 6 , 体温, 脈拍, 呼吸数, 酸素飽和度, 血液検查 デー夕を調査した。発作強度は，小発作，中発作，大発 作と呼吸不全の 4 段階に分類され，呼吸状態と生活状態 の程度によって評価した7)。血液検查デー夕は, 二酸化 炭素分圧 (partial pressure of carbon dioxide：以下, $\mathrm{pCO}_{2}$ ), 白血球数 (white blood cell : 以下, $\mathrm{WBC}$ ), 好 中球 (neutrophil : 以下, NEUT), 好酸球 (eosinophil granulocyte：以下, EOS), C 反応性蛋白 (C-reactive protein：以下, CRP) とした。 入院中治療経過は, 入院 から理学療法開始までの日数, 理学療法介入日数, 理学 療法介入平均単位数 /日，入院から酸素投与中止までの 日数，入院期間，胸部 $\mathrm{X}$ 線評価による新たな入院中無 気肺発症の有無を調查した。

対象を徒手的な呼吸介助手技を吸入時に実施していた Group A と実施していないGroup B の 2 群に分類し比 較検討した. Group Aには吸入時の呼吸介助手技は, 対 象者が背臥位または座位の姿勢を取り，理学療法士が胸 部に軽く手を密着させ，呼吸運動に合わせながら胸部を 圧迫介助した，Group B は呼吸介助手技を実施せず，安 楽な背卧位, 座位姿勢での吸入指導のみを実施した。な お，両群ともに理学療法士による呼吸評価，日中夜間の 体位管理，呼吸状態に応じた離床を段階的に行った。

統計解析は, 2 群間の背景, 入院時所見の比較には, 性別, 診断名, 無気肺発症の有無を Fisher の直接確率法, 発作強度を Mann-Whitney の $\mathrm{U}$ 検定, 体温, 脈拍, 呼 吸数, 酸素飽和度, $\mathrm{pCO}_{2}, \mathrm{WBC}, \mathrm{NEUT}, \mathrm{EOS}, \mathrm{CRP}$ を対応のない $\mathrm{t}$ 検定を行った。 入院中治療経過の比較に は, 入院から理学療法開始までの日数, 理学療法介入日 数, 理学療法介入平均単位数 $/$ 日, 入院加酸素投与中 止までの日数，入院期間を対応のない $\mathrm{t}$ 検定を行った. 統計解析ソフトはIBM SPSS Statistics Ver. 23 を用い, 有意水準は $5 \%$ とした。

本研究は, 東京女子医科大学倫理委員会の承認を得て 実施した（承認番号：5223）。

\section{III. 結 果}

対象は，検討期間中にリハビリテーション依頼のあっ た小児気管支喘息急性増悪患者 34 例のうち脳性麻盘の 診断を受けている児 2 例, 染色体異常・神経筋疾患を合 併した児 12 例を除外した 20 例（Group A 11 例，Group B 9 例）を解析対象とした。死亡した児は 0 例であった. 解析対象者の背景，入院時所見を表 1 に示した，全ての 
表 1 解析対象者の背景, 入院時所見

\begin{tabular}{|c|c|c|c|c|}
\hline & $\begin{array}{c}\text { 全体 } \\
(\mathrm{n}=20)\end{array}$ & $\begin{array}{c}\text { Group A } \\
(\mathrm{n}=9)\end{array}$ & $\begin{array}{c}\text { Group B } \\
(\mathrm{n}=11)\end{array}$ & $\mathrm{p}$ 值 \\
\hline 性別 男性 & $14(70.0)$ & $8(88.9)$ & $6(54.5)$ & 0.12 \\
\hline 年齢（歳） & $2.5 \pm 1.3$ & $2.2 \pm 1.4$ & $2.7 \pm 1.2$ & 0.40 \\
\hline \multicolumn{5}{|l|}{ 診断名 } \\
\hline 肺炎 & $13(65.0)$ & $6(66.7)$ & $7(63.6)$ & 0.63 \\
\hline 気管支炎 & $9(45.0)$ & $4(44.4)$ & $5(45.5)$ & 0.66 \\
\hline 上気道炎 & $1(5.0)$ & $0(0.0)$ & $1(9.1)$ & 0.55 \\
\hline \multicolumn{5}{|l|}{ 入院時所見 } \\
\hline 発作強度 & 小 0 例, 中 17 例, 大 3 例 & 小 0 例, 中 7 例, 大 2 例 & 小 0 例, 中 10 例, 大 1 例 & 0.43 \\
\hline 体温 $\left({ }^{\circ} \mathrm{C}\right)$ & $38.4 \pm 1.2$ & $38.5 \pm 1.0$ & $38.3 \pm 1.4$ & 0.78 \\
\hline 脈拍（回／分） & $149.8 \pm 20.5$ & $150.7 \pm 22.2$ & $149.0 \pm 20.0$ & 0.86 \\
\hline 呼吸数（回／分） & $41.1 \pm 11.9$ & $45.1 \pm 13.5$ & $37.8 \pm 9.8$ & 0.18 \\
\hline 酸素飽和度（\%） & $93.6 \pm 2.6$ & $93.9 \pm 1.9$ & $93.4 \pm 3.2$ & 0.67 \\
\hline \multicolumn{5}{|l|}{ 血液検査データ } \\
\hline $\mathrm{pCO}_{2}(\mathrm{mmHg})$ & $34.4 \pm 4.1$ & $34.2 \pm 3.8$ & $34.7 \pm 4.6$ & 0.79 \\
\hline WBC $\left(\times 10^{3} / \mu \mathrm{l}\right)$ & $11.3 \pm 5.3$ & $9.5 \pm 3.3$ & $12.8 \pm 6.2$ & 0.17 \\
\hline NEUT（\%) & $57.2 \pm 18.5$ & $55.7 \pm 17.0$ & $58.4 \pm 20.4$ & 0.75 \\
\hline EOS（\%) & $1.1 \pm 1.3$ & $0.5 \pm 0.6$ & $1.5 \pm 1.5$ & 0.07 \\
\hline $\mathrm{CRP}(\mathrm{mg} / \mathrm{dl})$ & $1.4 \pm 1.4$ & $1.5 \pm 1.6$ & $1.4 \pm 1.3$ & 0.10 \\
\hline
\end{tabular}

平均值 \pm 標準偏差, もしくは例数 (割合, \%). $\mathrm{pCO}_{2}$ : partial pressure of carbon dioxide, WBC : white blood cell, NEUT : neutrophil, EOS : eosinophil granulocyte, CRP : C-reactive protein.

表 2 入院中治療経過

\begin{tabular}{lcccc}
\hline & $\begin{array}{c}\text { 全体 } \\
(\mathrm{n}=20)\end{array}$ & $\begin{array}{c}\text { Group A } \\
(\mathrm{n}=9)\end{array}$ & $\begin{array}{c}\text { Group B } \\
(\mathrm{n}=11)\end{array}$ & $\mathrm{p}$ 值 \\
\hline 入院から理学療法開始までの日数 $($ 日) & $5.5 \pm 2.6$ & $5.9 \pm 2.9$ & $5.1 \pm 2.4$ & 0.51 \\
理学療法介入日数 $($ 日) & $3.1 \pm 1.5$ & $3.0 \pm 1.7$ & $3.1 \pm 1.4$ & 0.90 \\
理学療法介入平均単位数 $(/$ 日) & $1.6 \pm 0.4$ & $1.8 \pm 0.4$ & $1.4 \pm 0.3$ & $0.03 *$ \\
入院から酸素投与中止までの日数 $($ 日) & $7.5 \pm 1.9$ & $7.7 \pm 2.5$ & $7.4 \pm 1.3$ & 0.73 \\
入院期間 (日) & $9.8 \pm 2.2$ & $10.2 \pm 2.9$ & $9.5 \pm 1.5$ & 0.45 \\
無気肺発症の有無 & $0(0)$ & $0(0)$ & $0(0)$ & \\
\hline
\end{tabular}

平均值 \pm 標準偏差, もしくは例数（割合，\%). * : p $<0.05$.

対象者の背景, 入院時所見において 2 群間で有意差を認 めなかった。

治療は対象児全例に対して気管支拡張薬である $\beta 2$ 刺 激薬の吸入, 副腎皮質ステロイドの全身投与, 酸素投与 が行われた。 なお，酸素投与の中止は，日中および夜間 を含めた酸素飽和度の低下がない場合，退院は，酸素投 与の中止と著名な喀痰, 咳嗽がないことを確認し小児科 医師判断で決定された。

入院中治療経過を表 2 に示した。 入院から理学療法開 始までの日数, 理学療法介入日数は 2 群間で有意差を認 めなかった. 理学療法介入平均単位数において, Group B は Group A に比し, 有意に少なかった。 入院から酸 素投与中止までの日数, 入院期間は 2 群間で有意差を認
めなかった。入院期間中に胸部 X 線評価による無気肺 発症は全例で認めなかった。

\section{IV. 考 察}

本研究は，小児気管支喘息急性増覀患者に対する入院 中の呼吸理学療法の違いにより，徒手的呼吸介助手技実 施群, 非実施群の 2 群に分類し, 入院中治療経過につい て比較した。理学療法介入平均単位数は徒手的呼吸介助 手技実施群に比べ非実施群が少なく，この理由には徒手 的介助手技の実施時間の有無が影響したと考えられた。 また，入院から酸素投与中止までの日数，入院期間には 差がなかった。 
小児気管支喘息急性増悪患者治療の目的は, 症状のコ ントロール，早期退院による quality of life (QOL) の 向上だと考えられる. 今回, 入院から酸素投与中止まで の日数は, Group A（徒手的呼吸介助手技実施群） 7.7 \pm 2.5 日, Group B (非実施群) $7.4 \pm 1.3$ 日，入院期間 は, Group A $10.2 \pm 2.9$ 日, Group B $9.5 \pm 1.5$ 日（平 均 \pm 標準偏差）であり, 徒手的呼吸介助手技の有無に よる違いは認められなかった， 2 歳以上の幼児および成 人を対象としたSystematic Reviewにおいて，気管支喘 息に対する徒手的な介入を支持するエビデンスはまだそ しいことが報告されている ${ }^{8)}$ ．黑島ら ${ }^{4)}$ は, 平均年齢 7.4 歳の小児気管支喘息入院児に対して呼吸介助手技を実施 し, 介入時に小発作であったものは, $\mathrm{SpO}_{2}$, ピークフ ロー值が改善したが, 中・大発作には変化がなかった。 さらに, 咳嗽や呼吸数などの臨床症状の不変または増悪 により呼吸介助手技を中止したものが $41.9 \%$ いたこと が示されている。また，奥村ら 5) は，5歳未満の気管支 喘息入院患者 10 例に対して徒手的呼吸介助手技を実施 し，施行直後の酸素飽和度の上昇を認めた例が多かった が, 変化がなかったものや低下したものも含まれていた と報告している。これらの理由には, 乳幼児特有の解剖 学的, 生理学的特徵が挙げられる. 乳幼児は, 成人に比 べ気道の内径が細く, 肺の弾性収縮力も小さい. 気管支 平滑筋が少なく, 分泌物が多いこと, 側副換気が少ない という特徴を持つ ${ }^{9)}$. 気道内径がさらに細くなる気管支 喘息急性増悪時に徒手的呼吸介助手技を実施する場合, 急激な呼気流速の上昇により気道狭窄, 肺胞虚脱を助長 する可能性が考えられた。

また，気管支喘息急性増悪患者のうち無気肺の合併は, 酸素需要の増加, 細菌感染の契機, 入院期間の延長とな る可能性がある。先行研究において, 小児気管支喘息急 性増悪入院患者のうち無気肺の合併率は 4 19\% 10), 他 の検討では，低酸素血症を伴わない場合 $11 \%$, 伴う場 合 $36 \%$ と報告されている ${ }^{11)}$ 。本研究では，入院期間中 に2 群ともに新たに無気肺を併発した症例はいなかっ た。これは 2 群ともに日中と夜間の体位管理について同 室入院の介助者や看護師に指導していることが無気肺併 発の予防に寄与したと推察された。

研究の限界として, 本研究の対象者数は 20 名と少な く, 今後症例数を蓄積して検討していく必要があると考 えられる。また, 対象には 2 歳未満の乳児喘息様症状を 呈する患者も含まれてしまっている可能性がある。2 歳 未満では, RS ウイルス以外の迅速検査で容易に診断で きないウイルス感染による急性細気管支炎と気管支喘息 との鑑別が非常に困難であるといわれている ${ }^{12)}$ ，乳児 喘息を広義に捉えて, 2 歳未満の乳児喘息様症状を呈す
る患者に対しては気管支喘息に準じた治療を行うため, 今回の検討では呼吸理学療法の対象としている。今後は, 気管支喘息患者に有効な呼吸理学療法をより詳細に検討 するために気管支喘息の診断の確定した 5 歳以上での検 討が必要である。ささに、, 対象が低年齢であることから スパイロメトリーによる一秒量 $\left(\mathrm{FEV}_{1.0}\right)$ や努力性肺活 量（FVC）の測定を実施しておらず，今後これらの評価 を実施できれば気管支喘息自体に対する徒手的呼吸理学 療法の効果について検証できるかもしれない。なお，今 回の検討では神経学的異常のない正常小児気管支喘息急 性増悪患者を対象とした。気道や胸郭変形を伴う重度脳 性麻瘏患者や咳嗽能力の低下している神経筋疾患患者に はそれぞれ有効な呼吸理学療法についても検討していく 必要があるだろう。

利益相反 開示すべき利益相反はない.

\section{引用文献}

1) 厚生労働省: 人口動態調査 (平成 29 年人口動態統計の概況). http://www.mhlw.go.jp/toukei/list/81-1.html（閲覧日2019年 10 月 13 日)

2) 厚生労働省 : 患者調査 (平成 29 年患者調査), http://www. mhlw.go.jp/toukei/list/10-20.html(閲覧日2019年10月 13 日).

3) Rowe BH, Spooner CH, Ducharme FM, et al.: Corticosteroids for preventing relapse following acute exacerbations of asthma. Cochrane Database Syst Rev, 2007, 3: CD000195.

4) 黒島敬子, 清水貴士, 白木博文：小児喘息発作に対する呼 吸理学療法の有用性の検討. 日本小児難治喘息・アレルギー 疾患学会誌, 2004, 2: 27-31.

5) 奥村紀美恵, 坂田 宏: 乳幼児の喘息発作に対する呼吸理 学療法の効果. 日本小児呼吸器学会雑誌, 2000, 11: 133137.

6) 日本呼吸器学会：咳嗽・喀痰の診療ガイドライン 2019. メ ディカルビュー社, 東京, 2019.

7) 日本小児アレルギー学会：小児気管支喘息治療・管理ガイ ドライン 2017. 協和企画, 東京, 2017.

8) Hondras MA, Linde K, Jones AP: Manual therapy for asthma. Cochrane Database Syst Rev, 2005, 2: CD001002.

9) Hershenson MB, Colin AA, Wohl ME, et al.: Changes in the contribution of the rib cage to tidal breathing during infancy. Am Rev Respir Dis, 1990, 141: 922-925.

10) Maxwell GM: The problem of mucus plugging in children with asthma. J Asthma, 1985, 22: 131-137.

11) Tsai SL, Crain EF, Silver EJ, et al.: What can we learn from chest radiographs in hypoxemic asthmatics? Pediatr Radiol, 2002, 32: 498-504.

12) 日本小児アレルギー学会 : 小児アレルギー疾患総合ガイド ライン 2011. 協和企画, 東京, 2011. 